\title{
Two Types of Heuristics in Moral Decision Making
}

\author{
VITALIY NADURAK \\ Department of Philosophy, Sociology and Religious Studies, Vasyl Stefanyk Precarpathian National University, 57 Shevchenko Street, \\ Ivano-Frankivsk, 76018, Ukraine \\ Email:vnadurak@gmail.com
}

\begin{abstract}
Moral assessment implies ascribing a status of morally wrong, good, etc. (target attribute) to an act. Such an assessment is made on the basis of information about other attributes of the act, including its compliance with the norm, consequences, opinions of others about it, etc. These attributes may be morally relevant (those attributes that an individual could, in the case of rational analysis, recognize as a direct basis for moral assessment) and morally irrelevant (those which would not be recognized in such a status). A comprehensive moral assessment of the target attribute is an assessment based on all morally relevant attributes. A heuristic assessment is based only on a part of morally relevant attributes or based on morally irrelevant attributes. This difference between moral heuristics became the basis for dividing them into two types. Heuristics of the first type implies a simplified assessing of the target attribute based on partial information about morally relevant attributes of an act. The heuristic of the second type operates through a process of attribute substitution when irrelevant attributes are used to assess the target attribute.
\end{abstract}

Keywords: attribute substitution, moral assessment, morally relevant attributes, morally irrelevant attributes, moral heuristics

\section{INTRODUCTION}

The term 'heuristics' is widely used in studies devoted to decision-making. One consequence of the widespread use of this term is different interpretations of its meanings. Anuj K. Shah and Danie M. Oppenheimer have noticed that researchers have used the word so widely as to render it a vague, catch-all term for explaining decision processes (Shah, Oppenheimer 2008: 207). Given this, research on heuristics should begin with clarifying the meaning of this term.

Herbert Simon, the father of heuristics research in judgment and decision making, argued that heuristics are 'methods for arriving at satisfactory solutions with modest amounts of computation' (Simon 1990: 11). Gerd Gigerenzer writes that 'a heuristic is a mental process that ignores part of the available information and does not optimize, meaning that it does not involve the computation of a maximum or minimum' (Gigerenzer 2010: 529). Daniel Kahneman and Shane Frederick have defined heuristic through the process of attribute substitution: 'judgment is mediated by a heuristic when an individual assesses a specified target attribute of a judgment object by substituting another property of that object - the heuristic attribute - which comes more 
readily to mind' (Kahneman, Frederick 2002: 53). Shah and Oppenheimer posit that heuristics primarily serve the purpose of reducing the effort associated with a task. Therefore they define heuristics 'as methods that use principles of effort-reduction and simplification. By definition, heuristics must allow decision makers to process information in a less effortful manner than one would expect from an optimal decision rule' (Shah, Oppenheimer 2008: 207). The definition proposed by Shah and Oppenheimer will be taken as the basis in this study. Accordingly, the moral heuristics will be called methods that serve the purpose of reducing the effort associated with moral decision making. This definition is quite broad, but the considerations outlined in this article will allow explaining in what way effort is reducing. This will allow formulating a more specific definition of moral heuristics.

The study of moral heuristics was started a quite long time ago (Baron 1993; Messick 1993). However, the wider discussion and research unfolded after the publication of Cass Sunstein's article 'Moral Heuristics' (Sunstein 2005a; 2005b). Sunstein defines moral heuristics as moral short-cuts, or rules of thumb, that generally work well, but that also lead to mistaken and even absurd moral judgments (Sunstein 2005a: 531). As an example, he mentioned moral rules that prohibit an individual from knowingly causing a human death, stealing, lying, etc.; automatic emotional reactions, such as moral aversion to cannibalism or incest; simple methods for solving complex moral problems when, for example, unsure of what morality requires, what the law is, people might ask about the view of trusted authorities (a leader of the preferred political party, an especially wise judge, or a religious figure). At the same time, referring to Kahneman and Frederick (Kahneman, Frederick 2002), Sunstein writes that heuristics operate through a process of attribute substitution when people are interested in assessing a 'target attribute' and when they substitute a 'heuristic attribute' of the object, which is easier to handle (Sunstein 2005: 532). That is person aims to assess what morality requires, instead, assesses the view of trusted authorities and considers the answer to that question as an answer to the question what morality requires. Therefore, this process operates through a process of attribute substitution.

However, the examples given by Sunstein are phenomena of different kinds and, first of all, not all of them operate through a process of attribute substitution. For example, it is not clear how a process of attribute substitution works in the case of using 'don't lie' rule when a person having a possibility to lie automatically reminds this rule and refrains from lying. This answer is simple, fast, and does not require significant cognitive efforts, but the process of attribute substitution is absent here, because the person asks the question 'Is this lie?', and gives the answer exactly to this question. Shah and Oppenheimer pay attention to this discrepancy. They give an example of the Sunstein's heuristic 'punish, and do not reward betrayals of trust' and notice that it is not immediately clear whether this heuristic is truly operating via attribute substitution. This is not to say that Sunstein's moral heuristics are not heuristics at all. Indeed, they may work to reduce the effort associated with moral decision making. However, it may be that these heuristics 'reduce effort in some other way' (Shah, Oppenheimer 2008: 208).

So the contradiction can be explained by assuming that Sunsetin uses different interpretations of the heuristics without mentioning this. In one case, he calls heuristics those mental processes that operate via attribute substitution, and in others those that 'reduce effort in some other way'. This explanation is consistent with the conclusions of other researchers who have noticed various interpretations of heuristics in scientific literature.

Walter Sinnott-Armstrong and Fiery Cushman write that there are broad and narrow definitions of heuristics. In a narrow sense (which they accept) heuristics work by means of unconscious attribute substitution, in a broad sense, heuristics include any mental short-cuts or rules 
of thumb that generally work well in common circumstances but also lead to systematic errors in unusual situations (Sinnott-Armstrong, Cushman 2010: 250).

Matthew Liao has identified three ways of understanding intuitions as heuristics (although he has criticized the approach that identifies intuition with heuristics): (a) intuitions are heuristics that involve attribute substitution; (b) intuitions are heuristics that involve unconscious attribute substitution (he notices that obviously (b) is a subset of (a)); and (c) intuitions are heuristics that are fast and frugal and that make a more complex problem simpler (Liao 2016).

The aforementioned remarks on various interpretations of heuristics gave impetus to the writing of this article. It is hypothesized that under different interpretations of heuristics are actually different types of heuristics. This study aims to prove existence of two types of moral heuristics that differ by the mechanisms that are in their basis. Heuristics of the first type implies a simplified assessing of the target attribute based on partial information about it. The heuristic of the second type operates through a process of attribute substitution.

\section{TARGET ATTRIBUTE AND ITS COMPREHENSIVE ASSESSMENT}

In order to explain the differences between these types of heuristics, first of all it is necessary to find out what to consider as a target attribute in a moral judgment and which assessment is considered as comprehensive, that is the one compared to which heuristic moral assessment is simplified.

Sinnott-Armstrong and Cushman think that:

'The target attribute in a moral judgment is simply the attribute that the person who makes the judgment ascribes to the act, correctly or not. When someone judges that an act is morally wrong, the target attribute for that judgment is moral wrongness. When judging that someone is morally virtuous, the target attribute for that judgment is moral virtue. Similarly for judgments of moral goodness, rights, and so on' (Sinnott-Armstrong, Cushman 2010: 255).

It is worth agreeing with this definition with certain clarifications. Indeed, a person who makes a moral assessment of an action primarily wants to know whether this action is morally wrong, morally good, etc. That is, the attribute of the act that the person seeks to identify (the target attribute) is its moral wrongness, moral goodness. However, these attributes are always such that the person who makes the judgment ascribes to the act (although a person may regard them as an objective attribute of an act) based on information about other attributes of an act that he knows. The attributes that become the basis for such an assessment may be signs indicating compliance or non-compliance with the moral norm, consequences of action, its motives, etc. On the basis of these attributes a person makes a general moral assessment of the act - morally wrong, morally good, etc. Without information on such attributes, assessment is impossible. Two types of moral heuristics differ among themselves by the attributes that are the basis for moral assessment.

What does non-heuristic imply, that is, a comprehensive assessment of the morality of the act, compared to which a heuristic moral assessment is simplified? In other words, what set of attributes should a person choose for a moral assessment, so that such an assessment could be considered as a comprehensive assessment of the target attribute? The search for such a standard is complicated by the presence of various philosophical positions, which consider various attributes of the action to be important for the moral assessment. A successive supporter of deontological ethics will choose to assess the compliance with the norm, and a successive utilitarian will assess consequences. However, the normative aspect of the issue in this case does not matter. It is important that the individual recognizes a certain set of attributes as necessary 
for a comprehensive moral assessment of the act. Proceeding from this, a comprehensive moral assessment is a moral assessment that is based on the attributes that the individual would choose in the case of a consistent rational analysis.

What attributes, as a rule, become the basis for moral assessment? The list of attributes for such an assessment may include features that indicate compliance of the act with a moral rule (for example, in the case of theft - the act of taking possession of someone else's property without his consent, in the case of a murder - the act of deprivation of life), the consequences of the act, its motives, the degree of freedom of the person, the availability of the alternatives, etc. The vast majority of individuals in one way or another recognize the importance of these attributes of the act for its moral assessment, although the set of attributes and the significance of each of them will be different. To achieve the purpose of the article, a conditional individual who considers all these attributes to be important will be taken as an example for the analysis. The assessment of such an individual will be accepted as a standard of a comprehensive moral assessment of the act. The extent to which such an individual is typical does not matter. What is important is that in the case of rational analysis, individuals recognize a certain set of attributes of an act as important for its moral assessment, but in practice, as a rule, an assessment is made on the basis of several of them, for example, information on whether the act complies with a moral rule or to which of the most obvious consequences it leads.

\section{TWO TYPES OF ATTRIBUTES}

Attributes that become the basis for a moral assessment of an action can be divided into two types: morally relevant attributes and morally irrelevant attributes.

Morally relevant are those attributes that an individual could recognize, in the case of rational analysis, as a direct basis for moral assessment, and morally irrelevant are those which would not be recognized in such a status. A typical example of the attributes of the first type is the set of attributes that was given above (compliance with the norm, consequences, etc.). If a person makes an assessment on the basis of at least one of them, then his assessment refers specifically to the moral aspect of the act, that is, the one that he seeks to assess (target attribute).

However, the assessment can also be made on the basis of attributes that are not directly related to the moral assessment of the act (irrelevant), but are associatively related to it. Such attributes can be the feelings caused by this action, its prevalence in the environment of the person, the opinion of someone authoritative, etc. In this case, the person answers the questions 'What do I feel about that?', 'How do others act?', 'What would be done in this case by someone authoritative', etc. That is, he answers questions that do not relate to the moral status of an act (target attribute) in his moral assessment system. From the fact that this is done or not done by others, that this act causes pleasant emotions, that someone authoritative believes so, in no way follows that it is moral, since the basis for moral assessment should be attributes that a person recognizes as morally relevant. Of course, non-relevant information can be a useful basis for the right decision (if someone authoritative considers that this act is moral, the probability that it is so is indeed high). However, the answer to any of these questions cannot be considered as a direct answer to the question of the moral status of the act (target attribute) in the aforementioned moral assessment system. But the answer to the question 'Does this act comply with the norm?' is a direct answer to the question about its moral status.

A comprehensive non-heuristic assessment of the target attribute involves identifying all relevant attributes of the act and making a moral assessment on their basis. A heuristic assessment 
involves identifying only a part of the attributes, most often one, and making a moral assessment based on this limited information.

Since the basis for a heuristic assessment may be morally relevant and irrelevant attributes, it is advisable to distinguish two types of moral heuristics. Heuristic of the first type implies a simplified assessing of the target attribute based on partial information about morally relevant attributes of an act. Heuristic of the second type operates through a process of attribute substitution when irrelevant attributes are used to assess the target attribute.

The proposed understanding of heuristics, in fact, corresponds to the interpretation of heuristics by Gerd Gigenerzer in which heuristic is a mental process that ignores part of the available information (Gigenerzer 2010). However, at least in moral judgments, it matters which information remains for decision-making. Heuristic assessment of the first type leaves a certain part of the morally relevant information, ignoring the other part of it. Instead, a heuristic assessment of the second type ignores all morally relevant information and making an assessment based on the morally irrelevant information.

Consider the following example. A person faces a situation in which it becomes possible to take possession of what does not belong to him, although the moral status of such an act for him is not completely understandable (for example, in the case of taking possession of public property). He seeks to find out whether this action is morally good (target attribute). To do this, he would have to assess morally relevant attributes, but he assesses irrelevant attributes, giving, for example, the answer to the question 'How do others act?'. The received answer is taken as the answer to the question 'Is this act moral?'. In this case, a heuristic assessment of the second type, based on the attribute substitution mechanism described by Kahneman and Frederick, will take place.

In the case of a heuristic assessment on the basis of morally irrelevant attributes a person identifies an action as moral or not, based on only part of the morally relevant information (for example, the fact of possibly taking possession of someone's property that violates the rule 'do not steal'). The person does not resort to a lengthy and complex analysis of an act that would involve taking into account all relevant attributes. For a heuristic assessment, only a small part of the information is sufficient, although, of course, it is an important part - whether there was a fact of taking possession of someone's property (it can be argued that in this case there is a kind of 'one-reason' decision-making (Gigerenzer et al. 2008)). Of course, this heuristic assessment could also be based on another part of the information, for example, obvious consequences of the act, its motives, etc. However, I have focused on this kind of moral heuristics, assuming that in practice it happens more often.

For this kind of moral heuristics the name 'deontological heuristics' can be proposed - it is a heuristic assessment of the moral status of an act in which the main criterion for such a status is the fact of its compliance with the moral norm, principle or rule. It is worth noting that for some adherents of deontological ethics, the only necessary information for moral assessment of an act is information about the features that make it possible to classify an act as violating or not violating a moral rule. They do not consider motives and consequences as significant. That is, deliberately choosing such a method of moral assessment, which we call deontological heuristics, they often consider it as the only correct one. For them, such an assessment will not be heuristic, because in their system of moral assessment there is only one morally relevant attribute - compliance of the act with a moral rule. Deontological heuristics will only take place if the individual recognizes several attributes as relevant, but basis his assessment only on one of them - compliance of the act with a moral rule. 
Let us consider one more example. A colleague asks a person to help hide a small financial abuse. In order to find out whether this action is morally good (target attribute), a person has to assess its morally relevant attributes. Instead, he assesses his feelings, for example, empathy to a colleague (a morally irrelevant attribute) and, on the basis of this feeling, concludes that the action is moral. Thus, he used a moral heuristic of the second type based on the process of attribute substitution. If a person uses information, for example, about consequences of this action to assess its moral status (although, in fact, he will consider as morally relevant information, not only about consequences of the action, but also about its compliance with the norm, motives, etc.), this will be moral heuristics of the first type.

\section{REASONS FOR USING MORAL HEURISTICS}

The reasons that cause an individual to resort to a heuristic assessment of the first type, that is, heuristic assessment based on morally relevant attributes, are fairly obvious. Being limited in cognitive resources, under the pressure of external circumstances, for example, lack of information, individuals often take into account only part of the required information, hoping that the decision will be correct (Gigerenzer 2010: 534). Such a strategy of action may even be completely conscious and rationally justified. Gerd Gigerenzer insists that this type of heuristics may even be more accurate compared to assessments that take into account more information (Gigerenzer 2008).

A more difficult question is why individuals sometimes ignore morally relevant attributes and use the assessment of the non-target attribute. Carey Morewedge and Daniel Kahneman claim that the judgment of a target attribute automatically evokes assessments of related attributes (Morewedge, Kahneman 2010: 438). An attribute substitution occurs under the following conditions: (1) the target attribute is relatively inaccessible; (2) a semantically and associatively related attribute is highly accessible; and (3) the substitution of a heuristic attribute in the judgment is not rejected by the critical operations of System 2 (Kahneman, Frederick 2002: 54).

Hence, a person resorts to a heuristic moral assessment based on morally irrelevant attributes when morally relevant attributes are relatively inaccessible for assessment for various reasons, and morally irrelevant attributes are associatively related to them, accessible, and not rejected by System 2 - our conscious self.

The inaccessibility of morally relevant attributes can be due to various reasons. We can assume that one of them is the undesirability of their assessment: a person seeks to maintain a positive self-esteem, which may be damaged by the assessment of relevant attributes. Therefore, he subconsciously resorts to the attribute substitution. For example, in the case of taking possession of public property, the rule that prohibits doing so, is an unpleasant circumstance for an individual who has a strong desire to take possession of something. In this case, in the moral assessment of the act, he may ignore information that is harmful for his self-esteem, answering another question, for example, whether others do so. Having found the necessary precedents, he will perceive them as an affirmative answer to the question about the moral status of the act. In this way, an individual will not hurt self-esteem and, at the same time, he will take possession of the desired thing. Another possible reason may be the lack of knowledge about the norm relevant to a particular case. In such a situation, he may, for example, look for answers to the question of what would be done in this case by someone authoritative. For example, a young researcher does not know whether his deed violates scientific ethics. Norms that determine behaviour in this case are unknown to him. However, he can recall how his academic supervisor acted in this case and act according to his example. 
The important question is why a certain morally irrelevant attribute appears associatively related to the relevant attributes. The reasons for this are different. Let us consider some of them. One of the most obvious is the relationship between moral judgment and emotions (Borg et al. 2006; Crockett et al. 2010; Greene 2001; Haidt 2001; Koenigs et al. 2007; Moll et al. 2002). In part, this relationship is due to the fact that many actions that people consider moral are evolutionarily adaptive, since they, for example, promote social cooperation. Therefore, a person has an appropriate emotional reaction to them. Even the thought of these actions causes pleasant or unpleasant feelings. These feelings can become the heuristic attribute for moral assessment. That is, a kind of affect heuristic (Slovic et al. 2002) will take place in this case. Walter Sinnott-Armstrong and Fiery Cushman even think that affect heuristic might explain what is common to all (or many) of the other postulated moral heuristics (Sinnott-Armstrong, Cushman 2010: 261).

In the case of heuristics 'imitate-your-peers: do what the majority of your peers do' a person's tendency to imitate the behaviour of others is revealed (Gigerenzer 2010: 545). It is known that when an individual receives information that another person, at least slightly connected with him, has acted in a certain way, then he will act more willingly in this way. In one of the famous experiments, hotel guests were informed that the majority of guests reuse their towels, and this led to the growth of reusing towels. Moreover, normative appeals were most effective when describing group behaviour that occurred in the setting that most closely matched individuals' immediate situational circumstances (e.g. 'the majority of guests in this room reuse their towels') (Goldstein at al. 2010). Other studies have found that feeling connected to another individual who engages in selfish or dishonest behaviour leads people to behave more selfishly and less ethically themselves (Gino, Galinsky 2012). Thus, when an individual encounters difficulties in the moral assessment of an act, the associatively related question arises: 'What do others do in that case?' Information about the actions of others can replace the assessment of morally relevant attributes.

In general, finding out the reasons for the inaccessibility of morally relevant attributes and the reasons for the appearance of associative links between morally relevant and non-relevant attributes requires a separate study.

\section{CONCLUSIONS}

The considerations outlined in the article help to clarify the understanding of moral heuristics and the mechanisms that underlie them. First, at the beginning of the article, a fairly broad definition of moral heuristics was proposed as methods that serve the purpose of reducing the effort associated with moral decision making. Now it is necessary to add that the reduction of effort is due to limiting of the amount of information about the attributes of an act that an individual uses for moral assessment. Second, these attributes may be morally relevant (those attributes that an individual could, in the case of rational analysis, recognize as a direct basis for moral assessment) and morally irrelevant (those which would not be recognized in such a status). Third, the latter fact made it possible to distinguish two types of moral heuristics. The first type uses some of the morally relevant attributes for assessment, and the second type uses irrelevant attributes and works by means of attribute substitution. Fourth, if we accept the above understanding of moral heuristics, then it should be recognized that not all of them operate through a process of attribute substitution, because in some moral heuristics the target attribute is assessed, and not the other, associatively related to it. Simplification, but not substitution takes place in this case. 


\section{References}

1. Baron, J. 1993. "Heuristics and Biases in Equity Judgments: A Utilitarian Approach", in Psychological Perspectives on Justice: Theory and Applications, eds. B. A. Mellers and J. Baron. New York: Cambridge University Press, 109-137.

2. Borg, J. S.; Hynes, C.; Van Horn, J.; Grafton, S.; Sinnott-Armstrong, W. 2006. "Consequences, Action, and Intention as Factors in Moral Judgments: An fMRI Investigation”, Journal of Cognitive Neuroscience 185: 803-817.

3. Crockett, M. J.; Clark, L.; Hauser, M. D.; Robbins, T. W. 2010. "Serotonin Selectively Influences Moral Judgment and Behavior through Effects on Harm Aversion", Proceedings of the National Academy of Sciences 107(40): 17433-17438.

4. Gigerenzer, G. 2008. "Moral Intuition = Fast and Frugal Heuristics?”, in Moral Psychology, Volume 2: The Cognitive Science of Morality: Intuition and Diversity, ed. W. Sinnott-Armstrong. Cambridge, Massachusetts: MIT Press, 1-26.

5. Gigerenzer, G.; Martignon, L.; Hoffrage, U.; Rieskamp, J.; Czerlinski, J.; Goldstein, D. G. 2008. “OneReason Decision Making", in Handbook of Experimental Economics Results, eds. C. R. Plott and V. L. Smitt. Vol. 1. Amsterdam: North-Holland, 1004-1117.

6. Gigerenzer, G. 2010. "Moral Satisficing: Rethinking Moral Behavior as Bounded Rationality", Topics in Cognitive Science 2(3): 528-554.

7. Gino, F.; Galinsky, A. D. 2012. "Vicarious Dishonesty: When Psychological Closeness Creates Distance from One’s Moral Compass", Organizational Behavior and Human Decision Processes 119(1): 15-26.

8. Goldstein, N. J.; Cialdini, R. B.; Griskevicius, V. 2008. "A Room With a Viewpoint: Using Social Norms to Motivate Environmental Conservation in Hotels", Journal of Consumer Research 35(3): 472-482.

9. Greene, J. D.; Sommerville, B. R.; Nystrom, L. E.; Darley, J. M.; Cohen, J. D. 2001. "An fMRI Investigation of Emotional Engagement in Moral Judgment", Science 293(5537): 2105-2108.

10. Haidt, J. 2001. "The Emotional Dog and Its Rational Tail: A Social Intuitionist Approach to Moral Judgment", Psychological Review 108(4): 814-834.

11. Kahneman, D., Shane, F. 2002. "Representativeness Revisited: Attribute Substitution in Intuitive Judgment", in Heuristics and Biases: The Psychology of Intuitive Judgment, eds. T. Gilovich, D. Griffin and

D. Kahneman. New York: Cambridge University Press, 49-81.

12. Koenigs, M.; Young, L.; Adolphs, R.; Tranel, D.; Cushman, F.; Hauser, M.; Damasio, A. 2007. "Damage to the Prefrontal Cortex Increases Utilitarian Moral Judgements", Nature 446(7138): 908-911.

13. Liao, M. S. 2016. "Are Intuitions Heuristics?", in Moral Brains: The Neuroscience of Morality, ed. S. M. Liao. New York: Oxford University Press, 312-330.

14. Messick, D. 1993. "Equality as a Decision Heuristic", in Psychological Perspectives on Justice, eds. B. Mellers and J. Baron. New York: Cambridge University Press, 11-31.

15. Moll, J.; Oliveira-Souza, R.; Eslinger, P. J.; Bramati, I. E.; Mourao-Miranda, J.; Andreiulo, P. A.; Pesoa, L. 2002. "The Neural Correlates of Moral Sensitivity: A Functional Magnetic Resonance Imaging Investigation of Basic and Moral Emotions", Journal of Neuroscience 22(7): 2730-2736.

16. Morewedge, C. K.; Kahneman, D. 2010. "Associative Processes in Intuitive Judgment", Trends in Cognitive Sciences 14(10): 435-440.

17. Shah, A. K.; Oppenheimer, D. M. 2008. "Heuristics Made Easy: An Effort-Reduction Framework", Psychological Bulletin 134(2): 207-222.

18. Simon, H. A. 1990. "Invariants of Human Behavior", Annual Review of Psychology 41: 1-19.

19. Sinnott-Armstrong, W.; Young, L.; Cushman, F. 2010. "Moral Intuitions", in The Moral Psychology Handbook, eds. J. M. Doris and the Moral Psychology Research Group. New York: Oxford University Press, 246-272.

20. Slovic, P.; Finucane, M. L.; Peters, E.; MacGregor, D. G. 2002. “The Affect Heuristic", in Heuristics and Biases: The Psychology of Intuitive Judgment, eds. T. Gilovich, D. Griffin and D. Kahneman. New York: Cambridge University Press, 397-420.

21. Sunstein, C. R. 2005a. "Moral Heuristics", Behavioral and Brain Sciences 28(4): 531-542.

22. Sunstein, C. R. 2005b. "On Moral Intuitions and Moral Heuristics: A Response", Behavioral and Brain Sciences 28(4): 565-570.

23. Sunstein, C. R. 2008. "Fast, Frugal, and (Sometimes) Wrong", in Moral Psychology, Volume 2: The Cognitive Science of Morality: Intuition and Diversity, ed. W. Sinnott-Armstrong. Cambridge, Massachusetts: MIT Press, $27-30$. 
VITALIY NADURAK

\title{
Du euristikos moralinių sprendimų tipai
}

\begin{abstract}
Santrauka
Moralinis įvertinimas reiškia veiksmo, kaip gero arba blogo, vertinimą. Toks vertinimas paprastai atliekamas remiantis informacija, pavyzdžiui, apie pasekmes, atitiktị normoms, specifiniams požymiams ir kt. Požymiai gali būti moraliai relevantiški ir moraliai nereikšmingi. Visapusis moralinis požymio vertinimas yra pagrịstas visais moraliai relevantiškais požymiais. Euristinis vertinimas grindžiamas iš dalies moraliai relevantiškais požymiais ir iš dalies moraliai nereikšmingais požymiais. Šis skirtumas moralinėje euristikoje tapo pagrindu siekiant suskirstyti ją ja du tipus. Pirmo tipo euristika reiškia supaprastintą požymio vertinimą, pagrịstą daline informacija apie moraliai tinkamus veiksmo požymius. Antro tipo euristika akcentuoja požymio pakeitimo procesą, kai moraliniame vertinime panaudojami nereikšmingi požymiai.
\end{abstract}

Raktažodžiai: požymių sukeitimas, moralinis ịvertinimas, moraliai relevantiški požymiai, moraliai nerelevantiški požymiai, moralinè euristika 